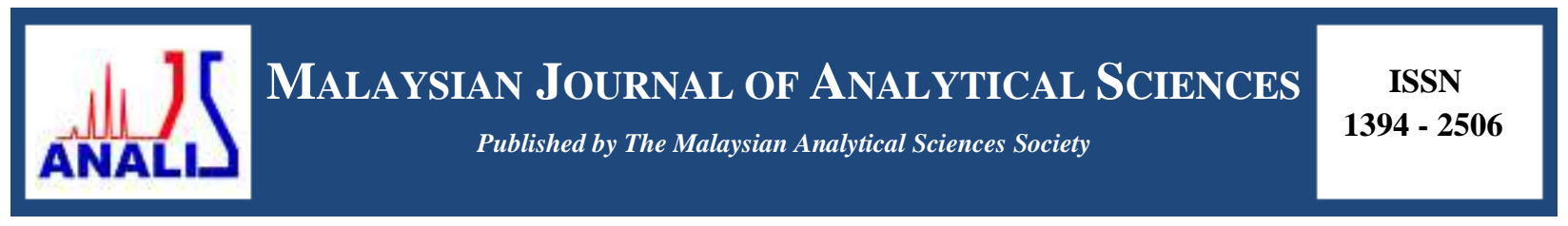

\title{
EFFECTS OF DEPOSITION TIME ON OF COBALT SULFIDE THIN FILM ELECTRODE FORMATION
}

\author{
(Kesan Tempoh Masa Enapan Terhadap Pembentukan Elektrod Filem Nipis Kobalt Sulfida) \\ Norshazlinah Abdul Karim ${ }^{1}$, Norasikin Ahmad Ludin ${ }^{1}$, Mohd Asri Mat-Teridi ${ }^{1}$, Suhaila Sepeai ${ }^{1}$, \\ Mohd Adib Ibrahim ${ }^{1}$, M. Kouhnavard ${ }^{2}$, Kamaruzzaman Sopian ${ }^{1}$, Hironori Arakawa ${ }^{3}$ \\ ${ }^{1}$ Solar Energy Research Institute (SERI), \\ Universiti Kebangsaan Malaysia, 43600 UKM, Bangi, Selangor, Malaysia \\ ${ }^{2}$ Malaysia-Japan International Institute of Technology (MJIT), \\ Universiti Teknologi Malaysia, 54100 Kuala Lumpur, Malaysia \\ ${ }^{3}$ Department of Industrial Chemistry, Faculty of Engineering, \\ Tokyo University of Science, 1-3 Kagurazaka, Shinjuku, Tokyo 162-0825, Japan \\ *Corresponding author: sheekeen@ukm.edu.my
}

Received: 12 April 2017; Accepted: 1 September 2017

\begin{abstract}
Cobalt sulfide counter electrodes (CE) were prepared using the electrodeposition and ionic exchange deposition method on the fluorine doped tin oxide (FTO). Time deposition effect of thin film were analyzed by using a field emission scanning X-ray diffraction (XRD), field emission electron microscope (FESEM), atomic force microscopic (AFM), and profilometry. The electrocatalytic activities of electrode were measured using cyclic voltammetry (CV) analysis. The growth of cobalt sulfide structure was confirmed by XRD. Therefore, the optimum deposition time of cobalt sulfide thin film electrode at 10 min was exhibiting the higher electrocatalytic activity with cathodic current and surface roughness of $-3.36 \mathrm{~mA} . \mathrm{cm}^{-2}$ and $34 \mathrm{~nm}$, respectively.
\end{abstract}

Keywords: cobalt sulfide, surface roughness, electrocatalytic activity, electrodeposition, ion exchange deposition

\section{Abstrak}

Elektrod lawan (CE) kobalt sulfida telah disediakan menggunakan teknik elektroenapan dan enapan pertukaran ion pada permukaan substrat fluorin terdop-timah oksida (FTO). Kesan tempoh masa enapan terhadap filem nipis telah di analisis menggunakan pembelauan sinar-X (XRD), analisis elektron imbasan pancaran medan (FESEM), mikroskop daya atom (AFM) dan profilometer. Keaktifan bermangkin bagi elektrod telah dianalisis menggunakan teknik kitaran voltamogram (CV). Elektrod kobalt sulfida pada tempoh masa enapan 10 min mempunyai keaktifan elektrobermangkin yang tinggi dengan nilai arus katod dan kekasaran permukaan, masing-masing adalah iaitu $-3.36 \mathrm{~mA} . \mathrm{cm}^{-2}$ dan $34 \mathrm{~nm}$.

Kata kunci: kobalt sulfida, kekasaran permukaan, keaktifan elektrobermangkin, elektroenapan, enapan pertukaran ion

\section{Introduction}

Cobalt sulfide is a metal sulfide group from inorganic material with formula $\mathrm{Co}_{x} \mathrm{~S}_{y}$ which has higher catalytic activity and is the one most preferred material for counter electrode $(\mathrm{CE})$, due to its electrocatalytic activity towards $\mathrm{I}_{3}{ }^{-}$reduction $[1,2]$. Cobalt sulfide exists in several type metal chalcogenide phases such as $\mathrm{Co}_{9} \mathrm{~S}_{8}, \mathrm{Co}_{3} \mathrm{~S}_{4}, \mathrm{CoS}_{2}$ and $\operatorname{CoS}[3,4]$. In 2009, cobalt sulfide was used as counter electrode in dye sensitized solar cell (DSSC) for the first time to replace platinum as counter electrode and shows the good catalytic activity for tri-iodide reduction then 
achieved $6.5 \%$ of efficiency [1]. The main role of counter electrode is to shift electrons arriving from the external circuit and catalyzes the reduction of tri-iodide and redox couple in electrolyte and then supplied back to the dye molecules [5]. Criteria for CE material for DSSC which are should have higher surface roughness, porous structure, and large active area for electrolyte to penetrate through the film easily [6,7]. Cobalt sulfide electrodes are produced via different techniques - electrodeposition [8], chemical bath deposition [9], and spray pyrolysis [10].

In this study, cobalt sulfide is coated onto fluorine-doped tin oxide (FTO) substrate by using electrodeposition and ionic exchange deposition method at different deposition time. It was expected that the deposition time of thin film subsequently effected the surface roughness and the electrocatalytic activity of cobalt sulfide thin film electrode in iodine-based electrolyte.

\section{Materials and Methods}

The CEs were prepared by using electrodeposition and ion exchange deposition methods were followed as previous report [11]. The electrodeposition of cobalt hydroxide $\left(\mathrm{Co}(\mathrm{OH})_{2}\right)$ was carried out in an aqueous deposition bath containing $5 \mathrm{mM}$ cobalt chloride hexahydrate $\left(\mathrm{CoCl}_{2} \cdot 6 \mathrm{H}_{2} \mathrm{O}\right)$ at ambient temperature. The electrodeposition had three electrode systems - an FTO substrate as the working electrodes (WE), platinum as a counter electrode (CE) and an $\mathrm{Ag} / \mathrm{AgCl}$ electrode as reference. The film was prepared by using equipment ModuLab, Solatron. The voltage used was fixed at $-0.8 \mathrm{~V}$ for different deposition time which were 5, 10, and 15 minutes. After the formation of the $\mathrm{Co}(\mathrm{OH})_{2}$ film, it was rinsed with deionized water, blown with flowing nitrogen gas and immersed in $100 \mathrm{mM}$ of $\mathrm{Na}_{2} \mathrm{~S}$ solution at $60^{\circ} \mathrm{C}$ for 2 minutes to facilitate ionic exchange reaction. Finally, the cobalt sulfide/FTO film was rinsed with deionized water and dried using nitrogen gas. The compositions of the films were characterized by an $\mathrm{X}$-ray diffraction (XRD, model Bruker D8 Advance). The surface roughness of the film was characterized using atomic force microscopic (AFM, model Nanosurf easyScan2) and the film thickness was measured by using profilometry (Model Dektak 150, Bruker). The morphology structures were characterized by field emission scanning electron microscope (FESEM, Carl Zeiss Supra 55VP). The electrocatalytic activities of thin films were analyzed by cyclic voltammetry (CV) techniques using potentiostats (ModuLab Solatron).

\section{Results and Discussion}

Figure 1 shows the surface roughness of cobalt sulfide films on FTO glass substrate measured using AFM. The average film thickness for 5, 10, and 15 minutes were measured by using profilometry were $141 \mathrm{~nm}, 266 \mathrm{~nm}$, and $341 \mathrm{~nm}$, respectively as listed in Table 1 . The average surface roughness is found to increase from $17 \mathrm{~nm}$ to $34 \mathrm{~nm}$ with the increase of deposition time up to 10 minutes and then decreased at 15 minutes with average surface roughness of $30 \mathrm{~nm}$. The thin film at 10 minutes time deposition formed higher surface roughness compared to other samples which is $34 \mathrm{~nm}$. For film at 15 minutes deposition time has lower surface roughness and due to the increase of film and flake thickness. According to Hsu et al., the surface roughness of the counter electrode will reflect the effective activity area for tri-iodide reduction and the large surface area of the thin film which contributed to more active site for electrolyte diffusion [12].
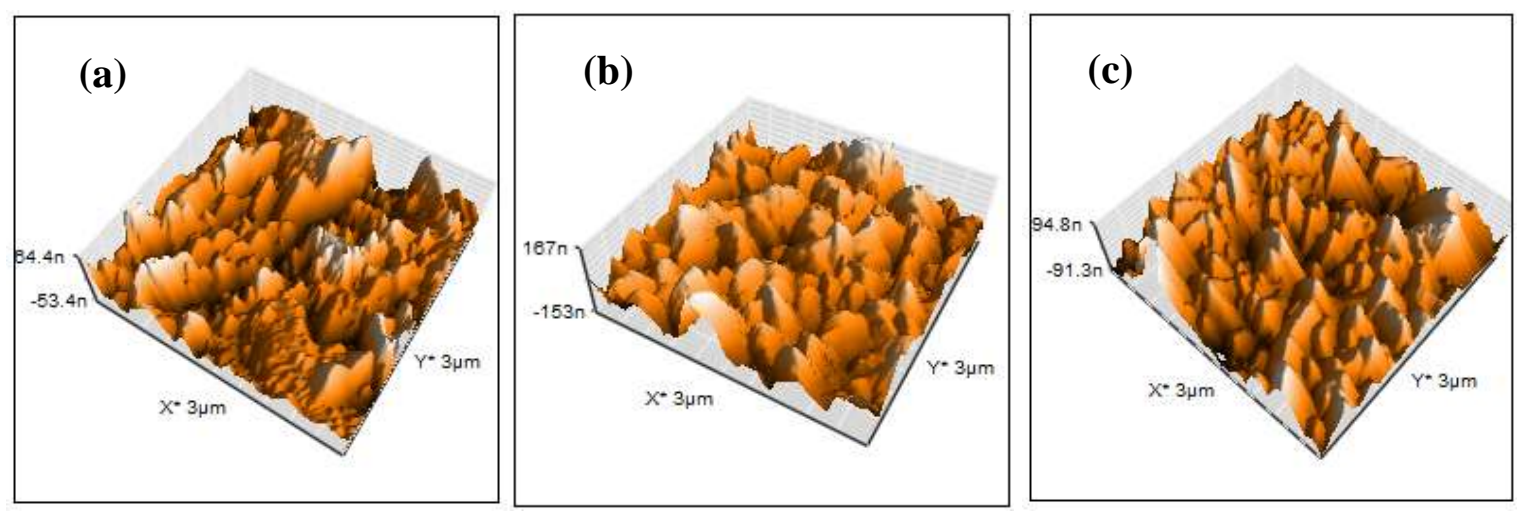

Figure 1. AFM topography images of cobalt sulfide thin film at (a) $5 \mathrm{~min}$, (b) $10 \mathrm{~min}$, and (c) 15 minutes 
The early formation of $\mathrm{Co}(\mathrm{OH})_{2}$ thin film using electrochemical deposition produces transparent and colorless film. After $\mathrm{Co}(\mathrm{OH})_{2}$ film was immersed in the $\mathrm{Na}_{2} \mathrm{~S}$ solution bath, the color of thin film changed to the black color. The color changed provides a preliminary indication of the formation of cobalt sulfide thin film as reported from previous literature [10]. Figure 2 shows the morphological structure the growth of cobalt sulfide mesoporous nanoflakes. The similar structure was reported by the previous literature [11, 13]. At the first 5 minutes time deposition, mesoporous nanoflakes is starting to grow but in small amount and not fully covered on FTO surface as shown by Figure 2(a). Whereas, Figure 2(b) indicates the growth of cobalt sulfide nanoflakes and covered the FTO surface. In Figure 2(c), the growth of cobalt sulfide is found to be increased and more compact in comparison to the 10 minutes time electrodeposition. The average thicknesses of flakes also found to be increased from 5 to 15 minutes of deposition time; which are $16 \mathrm{~nm}, 17 \mathrm{~nm}$ and $18 \mathrm{~nm}$. The distribution of cobalt and sulfur elements in the deposited cobalt sulfide thin film is illustrated in SEM images of Figure 2(d). The weight percentage (wt.\%) of Co and $\mathrm{S}$ were quantified by using energy dispersive X-ray spectroscopy (EDAX). It was found that, when the time deposition increased, the wt. \% of Co and S also increased as listed in the Table 2. From the calculated empirical formula, the deposited cobalt sulfide was found to have higher cobalt elements contents. This fact is most probably due to the uncompleted formation of cobalt sulfide deposited.
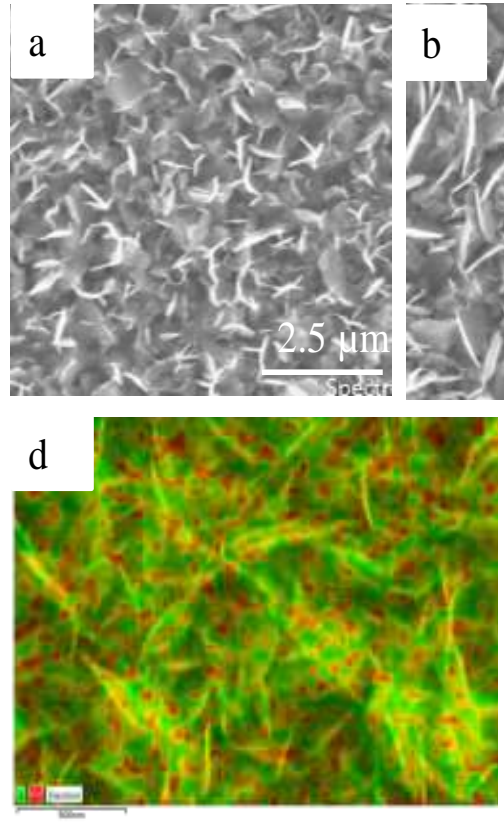
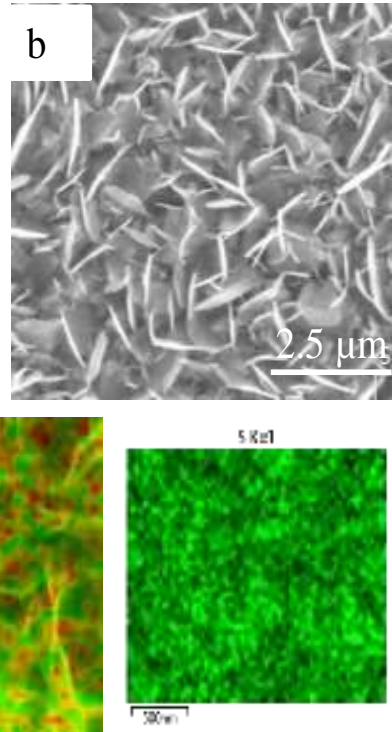

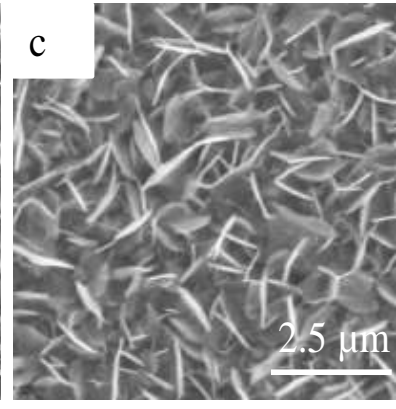

$\mathrm{Cn} \mathrm{knl}_{\mathrm{n}}$

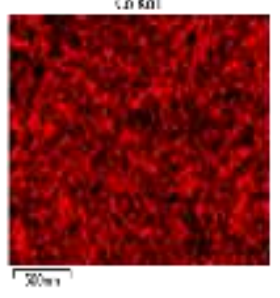

Figure 2. FESEM images of cobalt sulfide thin film deposited at (a) 5 (b) 10 (c) 15 minutes and d) is mapping picture to show the $\mathrm{Co}$ and $\mathrm{S}$ distribution (green color for sulfur and red color for cobalt)

Figure 3 shows the XRD pattern on the formation of cobalt sulfide analyzed by using X'pert HighScore software. Based on the diffraction pattern, diffraction of hexagonal $\mathrm{CoS}$ was obtained, and the structures were confirmed with JCPDS, PDF no. 00-001-1279. The CoS formation were existed for 5 minutes at $2 \theta=44.42^{\circ}$ and $47.40^{\circ}$, for 10 minutes at $2 \theta=44.42^{\circ}$ and $47.46^{\circ}$, and for 15 minutes at $2 \theta=44.50^{\circ}$ and $47.48^{\circ}$. The formation of $\operatorname{CoS}$ from $\mathrm{Co}(\mathrm{OH})_{2}$ is due to removal of $(\mathrm{OH})_{2}$ ion by replacing with sulfur sources, $\mathrm{Na}_{2} \mathrm{~S}$, then converted to the CoS thin film $[14,15]$. Cobalt (Co) was also identified at (100) with JCPDS, PDF no. 00-001-1277, confirming our previous speculation on EDX analysis. The intensity peak of CoS film increased due to the increment of thickness on FTO as deposition time increased. The stronger peaks of growth $\operatorname{CoS}$ is preferred orientation at plane (100) and (102). The peaks of FTO slightly reduced when the time deposition was increased due to the increment of film thickness. No changes were observed in the position of the CoS peaks when the time deposition was increased. The average crystallite size of $\mathrm{CoS}$ thin films has been calculated by using the equation Scherrer's formula in equation (1) [9]. 


$$
D=\frac{0.9 \lambda}{\beta \cos \theta}
$$

where $\lambda$ is the wavelength $\mathrm{X}$-ray $(0.15406 \mathrm{~nm}), \beta$ is full-width at the half maximum (FWMH) of diffraction peak and $\theta$ is diffraction angle. The result has given in Table 1 . The average crystallite size of CoS was estimated from Scherrer equation in between $20 \mathrm{~nm}$ to $47 \mathrm{~nm}$.

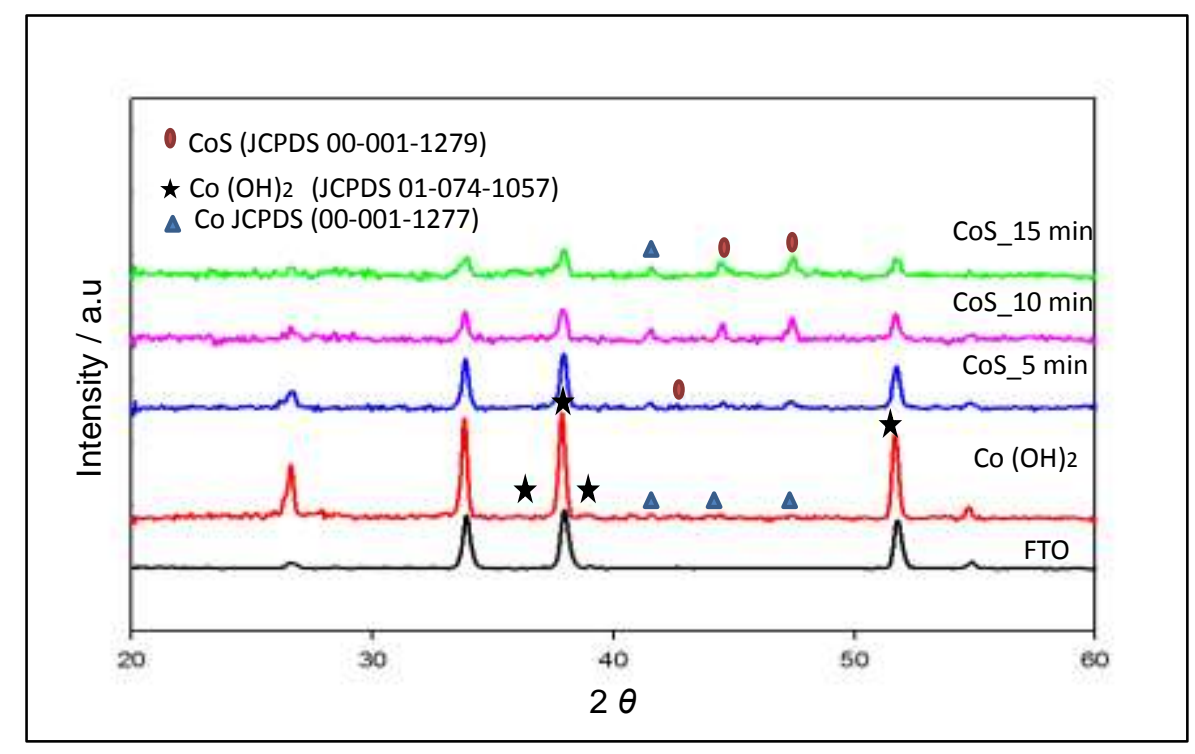

Figure 3. XRD pattern of $\mathrm{FTO}, \mathrm{Co}(\mathrm{OH})_{2}$ and as-deposited and $\mathrm{CoS}$ thin films for different deposition time

Table 1. The average crystallite size, flakes thickness, film thickness, and surface roughness of as-deposited cobalt sulfide thin film at 5,10 and 15 minutes of time deposition

\begin{tabular}{lcccc}
\hline $\begin{array}{l}\text { Deposition } \\
\text { Time } \\
(\mathbf{m i n u t e s})\end{array}$ & $\begin{array}{c}\text { Average Surface } \\
\text { Roughness }\left(\boldsymbol{R}_{\mathbf{a}}\right) \\
(\mathbf{n m})\end{array}$ & $\begin{array}{c}\text { Average Film } \\
\text { Thickness } \\
(\mathbf{n m})\end{array}$ & $\begin{array}{c}\text { Average Crystallite } \\
\text { Size }(\boldsymbol{D}) \\
(\mathbf{n m})\end{array}$ & $\begin{array}{c}\text { Average Flakes } \\
\text { Thickness } \\
(\mathbf{n m})\end{array}$ \\
\hline 5 & 17 & 141 & 47 & 16 \\
10 & 34 & 266 & 26 & 17 \\
15 & 30 & 341 & 20 & 18 \\
\hline
\end{tabular}

Table 2. The average of weight percentage (wt. \%) for Co and S element from EDAX

\begin{tabular}{lccc}
\hline $\begin{array}{l}\text { Deposition Time } \\
\text { (minutes) }\end{array}$ & $\begin{array}{c}\text { Co } \\
\text { (wt. \%) }\end{array}$ & $\begin{array}{c}\text { S } \\
\text { (wt. \%) }\end{array}$ & $\begin{array}{c}\text { Calculated } \\
\text { Empirical Formula }\end{array}$ \\
\hline $0 \mathrm{~min}$ & 100 & - & $\mathrm{Co}$ \\
$5 \mathrm{~min}$ & 75.55 & 24.44 & $\mathrm{Co}_{1.7} \mathrm{~S}$ \\
$10 \mathrm{~min}$ & 72.58 & 27.42 & $\mathrm{Co}_{1.4} \mathrm{~S}$ \\
$15 \mathrm{~min}$ & 71.43 & 28.57 & $\mathrm{Co}_{1.4} \mathrm{~S}$ \\
\hline
\end{tabular}


The cyclic voltammetry is used to evaluate the catalytic activity of cobalt sulfide thin film on FTO substrate in iodide-based electrolyte. The deposited CoS electrode was analyzed by cyclic voltammetry (CV) using a threeelectrode configuration in acetonitrile solution contains of $10 \mathrm{mM} \mathrm{LiI}, 1.0 \mathrm{mM} \mathrm{I}$ and $0.1 \mathrm{M} \mathrm{LiClO}_{4}$. Figure 4, shows two pairs of reversible redox peaks were observed for cobalt sulfide electrodes and the results are listed in Table 3. The left pair is represented by reduction equation (2) and right pair is represented by reduction equation (3) [16].

$$
\begin{aligned}
& \mathrm{I}_{3}+2 \mathrm{e}^{-} \leftrightharpoons 3 \mathrm{I}^{-} \\
& 3 \mathrm{I}_{2}+2 \mathrm{e}^{-} \leftrightharpoons \\
& 2 \mathrm{I}_{3}^{-}
\end{aligned}
$$

The left position at cathodic peak is related to catalytic activity of $\mathrm{CoS}$ electrode to reduce tri-iodide $\left(\mathrm{I}_{3}^{-}\right)$to iodide (I) ion which attributed by the redox reaction of equation 2 [17]. The film electrode without sulfurization showed the poor electrocatalytic activity in designated electrolyte by showing an oxidation peak only. This is due to noncatalytic behavior of $\mathrm{Co}(\mathrm{OH})_{2}$ film. The reduction peak appeared only after sulfurization and the formation of $\mathrm{CoS}$ after sulfurization is proved by the increased in catalytic activity of electrochemical reaction of $\mathrm{I}_{3}^{-}$to $\mathrm{I}^{-}$. The highest electrocatalytic activity was obtained by $\mathrm{CoS}$ film electrode at 10 minutes of deposition time when the cathodic peak potential towards positive value $(-0.144 \mathrm{mV})$ and cathodic peak current towards a negative value $(-3.36$ $\mathrm{mA} . \mathrm{cm}^{-2}$ ) in comparison to others deposition time. Thus, the increasing of cathodic current density is determined a faster rate for the reduction of $\mathrm{I}_{3}^{-}$as indicated by Wu et al. [17]. The increased in catalytic activity might be due to the increases of surface roughness and smaller crystallite size of $\operatorname{CoS}$ film electrode. According to previous report, the higher surface roughness and smaller CoS nanoflake crystallite size can promotes more active surfaces area for tri-iodide reduction, thus enhancing the catalytic activity of the CoS electrode $[12,18]$.

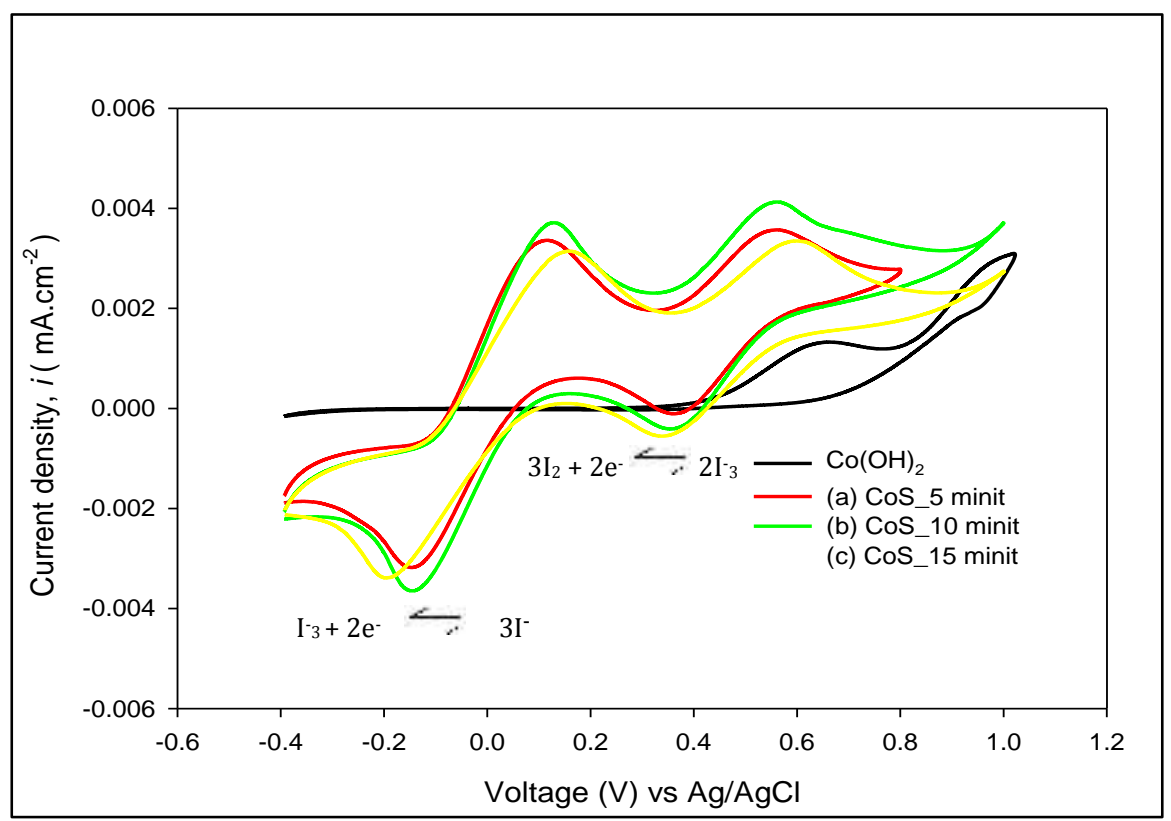

Figure 4. Cyclic voltammetry (CV) graphs of thin film before and after sulfurization, at 5, 10, and 15 minutes of deposition time 
Table 3. Cathodic current density and potential of cobalt sulfide electrode for different time deposition

\begin{tabular}{lcc}
\hline $\begin{array}{l}\text { Deposition Time } \\
(\text { minutes) }\end{array}$ & $\begin{array}{c}\text { Cathodic Current Density } \\
\left(\mathbf{m A . c m} \mathbf{-}^{-2}\right.\end{array}$ & $\begin{array}{c}\text { Cathodic Potential } \\
(\mathbf{m V})\end{array}$ \\
\hline 0 & - & - \\
5 & -3.18 & -0.15 \\
10 & -3.65 & -0.15 \\
15 & -3.39 & -0.19 \\
\hline
\end{tabular}

\section{Conclusion}

Cobalt sulfide was successfully deposited via electrodeposition and ionic exchange deposition. cobalt sulfide formed are found to be in nanoflakes architectural with porous structure and also gives high surface roughness. The highest surface roughness and smaller crystallite size was obtained at $10 \mathrm{~min}$ of deposition time showed higher electrocatalytic activity of $\mathrm{I}_{3}^{-}$to $\mathrm{I}^{-}$reduction. These preliminary result shows that the cobalt sulfide thin film electrode is promising to be used as counter electrode in electrochemical cells, especially dye sensitized solar cell (DSSC).

\section{Acknowledgement}

This research was supported by Ministry of Education (MOE) Malaysia under Exploratory Research Grant Scheme (ERGS/1/2012/TK07/UKM/03/5) and Look East Policy Grant (LEP 2.0/14/UKM/NT/03/1). This paper was presented in UKM-UCA international joint seminar on Science and Technology 2016.

\section{References}

1. Wang, M., Anghel, A. M., Marsan, B., Cevey Ha, N.-L., Pootrakulchote, N. Zakeeruddin, S. M. and Grätzel, M. (2009). CoS supersedes Pt as efficient electrocatalyst for triiodide reduction in dye-sensitized solar cells. Journal of the American Chemical Society, 131(44): 15976-15977.

2. Lin, J.-Y., Liao, J.-H. and Wei, T.-C. (2011). Honeycomb-like CoS counter electrodes for transparent dyesensitized solar cells. Electrochemical and Solid-State Letters, 14(4): 41.

3. Ramasamy, K., Malik, M. A., Raftery, J., Tuna, F. and O’Brien, P. (2010). Selective deposition of cobalt sulfide nanostructured thin films from single-source precursors. Chemistry of Materials, 22(17): 4919-4930.

4. Eze, F. C. and Okeke, C. E. (1997). Chemical-bath-deposited cobalt sulphide films: Preparation effects. Materials Chemistry and Physics, 47, 31-36.

5. Lee, K. S., Lee, H. K., Wang, D. H., Park, N.-G., Lee, J. Y., Park, O. O. and Park, J. H. (2010). Dye-sensitized solar cells with Pt- and TCO-free counter electrodes. Chemical Communications, 46(25): 4505-4507.

6. Hauch, A. and Georg, A. (2001). Diffusion in the electrolyte and charge-transfer reaction at the platinum electrode in dye-sensitized solar cells. Electrochimica Acta, 46(22), 3457-3466.

7. Papageorgiou, N. (2004). Counter-electrode function in nanocrystalline photoelectrochemical cell configurations. Coordination Chemistry Reviews, 248, 1421-1446.

8. Lin, J., Liao, J. and Chou, S. (2011). Cathodic electrodeposition of highly porous cobalt sulfide counter electrodes for dye-sensitized solar cells. Electrochimica Acta, 56(24): 8818-8826.

9. Kamble, S. S., Sikora, A., Pawar, S. T., Maldar, N. N. and Deshmukh, L. P. (2015). Cobalt sulfide thin films: Chemical growth, reaction kinetics and microstructural analysis. Journal of Alloys and Compounds, 623: 466472.

10. Chang, S. H., Lu, M. De, Tung, Y. L. and Tuan, H. Y. (2013). Gram-scale synthesis of catalytic $\mathrm{Co}_{9} \mathrm{~S}_{8}$ nanocrystal ink as a cathode material for spray-deposited, large-area dye-sensitized solar cells. ACS Nano, 7 , 9443-9451.

11. Tai, S.-Y., Chang, C.-F., Liu, W.-C., Liao, J.-H. and Lin, J.-Y. (2013). Optically transparent counter electrode for dye-sensitized solar cells based on cobalt sulfide nanosheet arrays. Electrochimica Acta, 107: 66-70.

12. Hsu, S., Li, C., Chien, H., Salunkhe, R. R., Suzuki, N., Yamauchi, Y. and Ho, K. -C. (2014). Platinum-free counter electrode nanoparticles for efficient. Scientific Report, 4:1-6. 
13. Chae, S. Y., Hwang, Y. J., Choi, J.-H. and Joo, O.-S. (2013). Cobalt sulfide thin films for counter electrodes of dye-sensitized solar cells with cobalt complex based electrolytes. Electrochimica Acta, 114: 745-749.

14. Rao, S. S., Gopi, C. V. V. M., Kim, S., Son, M., Jeong, M., Savariraj, A. D., Prabakar, K. (2014). Cobalt sulfide thin film as an efficient counter electrode for dye-sensitized solar cells. Electrochimica Acta, 133: 174179.

15. Hu, G., Orkoulas, G. and Christofides, P. D. (2009). Regulation of film thickness, surface roughness and porosity in thin film growth using deposition rate. Chemical Engineering Science, 64: 3903-3913.

16. Hauch, A. and Georg, A. (2001). Diffusion in the electrolyte and charge-transfer reaction at the platinum electrode in dye-sensitized solar cells. Electrochimica Acta, 46(22): 3457-3466.

17. Wu, M., Wang, Y., Lin, X., Yu, N., Wang, L., Wang, L., Hagfeldt, A. (2011). Economical and effective sulfide catalysts for dye-sensitized solar cells as counter electrodes. Physical chemistry chemical physics, 13(43): 19298-19301.

18. Yang, J., Bao, C., Zhu, K., Yu, T., Li, F., Liu, J., Li, Z. (2014). High catalytic activity and stability of nickel sulfide and cobalt sulfide hierarchical nanospheres on the counter electrodes for dye-sensitized solar cells. Chemical Communications, 50(37): 4824-4826. 